\title{
Emergencies in Migrant and Refugee Health 2015-2018 (letter)
}

\author{
E. Kalavsky (Erich Kalavsky)², G. Herdics (Georgy Herdics)', J. Vallova (Jana Vallova)1, \\ 5. Subramaniam (Selvaraj Subramaniam)², J. Bydzovsky (Jan Bydzovsky)', \\ J. Ridosko (Jaroslav Ridosko)3), T. Simonek (Tomas Simonek)², M. Palun (Miroslav \\ Palun)², P. Vansac (Peter Vansac)', A. Naddour (Annemarie Naddour)², J. Suvada \\ (Jose Suvada)²
}

${ }^{1}$ SEUC Refugee and Migrant Health Program, Bratislava, SK

Original Article

${ }^{2} \mathrm{MSc} /$ Nutrition Program Kuala Lumpur, Malaysia

${ }^{3}$ University Hospital Trencin, SK

\section{E-mail address:}

houseoffamily@hotmail.com

\section{Reprint address:}

Erich Kalavsky

House of Family

PnomPenh, KH

Source: Clinical Social Work and Health Intervention

Volume: 9

Issue: 3

Pages: 56 - 57

Cited references: 4

\section{Reviewers:}

Daria Kimuli - pechacova.daria@gmail.com

Mageswari Rajoo-m-rajoo@hotmail.com

\section{Key words:}

Refugees. Migrants. Emergencies.

\section{Publisher:}

International Society of Applied Preventive Medicine i-gap

CSWHI 2018; 9(3): 56 - 57; DOI 10.22359/cswhi_9_3_06 @ 2018 Clinical Social Work and Health Intervention

Sir,

Several papers in Clinical Social Work They have been suspected to be related to and Health Interventions have been related to spectrum of either communicable or non-communicable diseases (1-4). However none of them report emergency situations. PTSD, asthma, coronary heart disease, hypertension and diabetes; all diseases which will exacerbate with acute stress; conditions refugees and migrants must tolerate 
during their stressful journey to EU. Table 1 shows the commonest emergencies in various Health Checkpoints and Health Centers near Refugee Camps, for example in Hegyeshalom (HU), Dobova (SLO), Veria (GR), Lesbos (GR). The commonest emergency was diabetic coma, followed by status asthmaticus, acute bleeding during birth and hypertension crisis. Surprisingly, no death was recorded in any of those events despite of the large number of migrants coming via the Balkan Route.

Table 1: RList of commonest emergency events for acute care

\begin{tabular}{|l|c|c|}
\hline Event & No. & Deaths \\
\hline Birth bleeding & 12 & 0 \\
\hline Bleeding wounds & 8 & 0 \\
\hline Tentamen Suicidi & 2 & 0 \\
\hline Diabetic coma & 16 & 0 \\
\hline Myocardial infarction & 7 & 0 \\
\hline Status asthmaticus & 6 & 0 \\
\hline
\end{tabular}

\section{References}

1. MOLNAROVA K, ONDOVA P, ZOLLER $\mathrm{K}$, ADAMCOVA A et al. (2017) Low Number of Neuroinfections in Migrants to Greece from Syria and Iraq Comparison to Migrants from Burundi and Congo to Rwanda. Clinical Social Work and Health Intervention Vol. 8 No. 22017.

2. BELOVICOVA M, LISKOVA A, HRINDOVA T et al. (2017) Low Prevalence of MRSA in Physiotherapy and Gym Facilities in a Greek Refugee Camp. Clinical Social Work and Health Intervention Vol. 8 No. 22017.

3. KHALED I, ALI HAJJ P, KRCMERY V, KALATOVA D, GALLOVA A, BAK T, SCHUMMAN I, DUDOVA Z, ZOLLER $\mathrm{K}$, REITH B, OBTULOVIC M, OLAH M, HRINDOVA T, BELOVICOVA M (2017) Spectrum of infections in physiotherapy and rehabilitation ward for war victims and veterans from Iraq and Syria (short note). Clinical Social Work and Health Intervention. 8. 26-28. 10.22359/cswhi_8_2_05.

4. HAJJ PA et al. (2016) Are migrants from Middle East carriers of multi-resistant bacteria? Clinical Social Work and Health Intervention Vol. 7 No. 320162. 